\title{
Focusing on Language and Meaning While Learning With Text
}

\author{
ANNEMARIE S. PALINCSAR AND MARY J. SCHLEPPEGRELL \\ University of Michigan
}

Ann Arbor, Michigan, United States

doi: $10.1002 /$ tesq. 178

- English learners (ELs) in the United States have too often been denied access to rich and complex texts, especially informational texts (August \& Shanahan, 2006). This is highly problematic because access to texts is integral to building content knowledge, expanding vocabulary, and nourishing students' interests and motivations to read. Recognizing the importance of informational text in the reading diets of students, the Common Core State Standards recommend that, over the course of students' careers, the balance of opportunity should shift, with each grade level, toward the reading of informational text.

One of our primary goals has been to ensure that rich and complex informational texts have a presence in the curriculum of elementary grade English learners. But this is only the beginning. English learners then need support in accessing the ideas in these texts. Teachers can provide this support by building prior knowledge (Goldenberg, 2008), using graphic organizers to teach text structure (Echevarria, Short, \& Powers, 2006), and through vocabulary instruction (Vaughn et al., 2009). It has also been well documented that, even when English learners have word-reading skills in the average range, syntactic awareness persists as an area of difficulty and impedes comprehension (Lesaux \& Geva, 2006). This means that learners also need help understanding how language works at a discourse level, where linguistic choices of different kinds build meaning in a text. To respond to these learner needs we have been developing approaches that support teachers in talking with learners about how English works in the texts they encounter and produce in school contexts.

The primary tool that we have been drawing on, in collaboration with teachers in Grades 2 through 5, is the metalanguage associated with systemic functional linguistics (SFL) (Halliday \& Matthiessen, 2004; see Eggins, 2004, for an introduction). Metalanguage refers to language about language and includes both using terminology to refer to language as well as engaging in talk about language and meaning (Schleppegrell, 2013). To illustrate, consider the following. A segment 
from an earth science text states: "The wind and water are examples of natural causes of erosion. But people cause erosion too." When a teacher asks, "What does it mean that the author has started this sentence with the connector but?" she is using metalanguage to help students recognize that but signals something unexpected in a text. This provides useful information that readers can use to interpret and learn from that text at the same time they develop knowledge about language for reading other texts as well. In this instance, readers are on notice that to understand erosion of the earth's surface, one must look to both natural causes, such as wind and water, and also to human activity.

Our vision is that children develop and hone the use of metalanguage as a tool in the context of lively discussion, argumentation, and collaborative talk about text. In this brief report, we will identify the conceptual framework and guiding principles informing our research, describe the context in which we are conducting this research, and illustrate the ideal enactment of instruction informed by our framework.

\section{THEORETICAL FRAMEWORK AND GUIDING PRINCIPLES}

The theories of language that inform our work come from sociocultural theory; in particular, the writing of Vygotsky (e.g., 1986) and Halliday (e.g., 1978). Both Vygotsky's and Halliday's theories are also theories of language development with implications for education (Wells, 1994). Key tenets of their theories are that children learn by participating in interactions with others, and so simultaneously learn language and learn to do the things that the community (in this case, the classroom community) does with language. Children's learning is supported when their meanings are co-constructed by interlocutors who follow their intentions and support their meaning-making through assistance that builds on what they know and leads them toward new learning. Hence, our perspective is consistent with emergentist views of second language (L2) development that prescribe interaction and feedback in meaningful contexts, supported by explicit attention to language itself (e.g., Ellis \& Larsen-Freeman, 2006).

Informed by these theories, we have adopted the following principles in our research and development project:

- Second language learning, in contexts of schooling, is best supported through opportunities for children to engage in interaction with each other and the teacher in meaningful curricular activities. 
- Second language learning and teaching needs to be responsive to children's level of cognitive development, using grade-level content that supports instructional goals, as determined by national, state, and district standards, for which children and teachers are held accountable.

- With appropriate scaffolding, L2 learners can participate in complex meaning-making activities. Consistent with sociocultural theory, we conceive of scaffolding as a process in which teachers and students negotiate meaning while participating in shared activities within a supportive context (Palincsar, 1998). For example, while reading the earth science text referred to above, the class is collectively discussing how the information in the text is supporting them to understand why - and under what conditions - we have earthquakes and volcanoes; this is the shared activity. Furthermore, the teacher uses graphics and video to enhance the students' sense-making of the ideas in the text; these are examples of supports. In addition, these discussions highlight an additional source of support: conversations about the language of the text itself. This brings us to our next principle.

- Students' attention needs to be focused on the ways language works to make meanings in the texts they read and write. Metalanguage is a resource for this, and the power of metalanguage is enhanced when children experience metalanguage use as readers and writers and through talk about text.

- Even young children can be supported to learn about the domain-specific ways in which language is used (e.g., science texts are often written to provide descriptions and/or explanations; metalanguage can provide insight into how the author is advancing descriptions and/or explanations). In our case, the text is selected so that it is developmentally appropriate; the demands of the text and the purposes for reading, in turn, determine what aspects of the metalanguage are appropriate.

\section{CONTEXT OF OUR LANGUAGE AND MEANING RESEARCH AND DEVELOPMENT}

We have been conducting research with second- through fifth-grade teachers and students in an urban context in the Midwestern United States where the majority of the children in the classrooms are English learners who speak Arabic, and for whom-in some cases-Arabic is 
the dominant language in their homes and community. In this context, many of the children have limited opportunities to engage with the language of school subjects in their out-of-school experiences. To support the teachers in this context, we are developing tools and practices that teachers can use to (a) engage children in close analysis of meaning in text, (b) talk about the language of those texts to support children's literacy development in English, and (c) enable children to use the language they are learning in their own writing.

We are using an iterative design process in which we partner with the teacher participants in our research to develop curricula (texts and lessons) that are consistent with the district's educational standards, pilot those curricula in select classrooms, revise the curricula, conduct professional development with all of the participating teachers, carefully observe teacher enactment of the curricula in case-study classrooms and collect measures of student learning, and then revise the curricula, informed by these data. Our goal is to identify ways that the metalanguage of SFL can support children in talk, reading, and writing in grade-level curricular activities.

\section{AN ILLUSTRATION}

We present an abbreviated example of our curriculum and instruction, drawing from lessons that were designed to support children to read science texts and write arguments that drew upon evidence from those texts. In the reading activities, teachers and children explored how meaning is presented at the level of the sentence and the text as a whole. Teachers learned specific strategies for focusing children on ways they can argue for a position using text-based evidence-helping students make a claim, cite textual evidence to support that claim, and say how that evidence links back to the claim. These are key expectations of the new Common Core State Standards that teachers in the United States need help in implementing.

We scaffolded both the reading and the writing through talk about language and meaning, using a variety of strategies from sociocultural theory more generally and from functional linguistics in particular. We have little space here to report on the full range of activities we supported, but will focus on one language feature of science that is relevant both for reading and writing: the notion of likelihood. In our curriculum, calling attention to the ways that authors signal likelihood occurs opportunistically. The text selection drives the choice to teach likelihood; and moreover, whereas teachers might step outside the text to offer a mini-lesson on likelihood and give children practice identifying language forms that present likelihood (see discussion below), the 
expectation is that students are refining their understanding of likelihood in the context of reading and interpreting text in which it is important to consider issues related to likelihood.

Careful use of linguistic resources for expressing likelihood is important in writing about science, where writers need to present evidence in ways that accurately reflect the state of knowledge about that evidence. Writers need to indicate whether the evidence they cite definitely supports a claim or only shows some degree of support for a claim. One focus our instruction took, then, was on the language resources that authors use to temper the strength of a claim or to indicate certainty about the evidence presented. Likelihood calls for use of modality, a grammatical system that is known to be challenging to ELs because it uses language that conveys subtle degrees of commitment. In addition, the grammar of likelihood draws on a range of language resources including modal verbs (may, could, might), modal adjuncts (maybe, possibly), adjectives (the potential value...), nouns (there is a possibility that...), whole clauses (it is likely that...; it is possible that...) and other language forms. Whereas we share the metalanguage terminology with teachers, with the belief that this is useful content knowledge for teaching, the focus of the conversation with the students is on the language itself, in context.

Teachers begin by introducing students to the concept of likelihood - that authors often show how likely something is to happen and/or how sure it is. Teachers and students first explore the ways likelihood is used in talking about everyday concepts (e.g., discussing whether it will rain tomorrow), and then explore how the same language resources are used in science texts. Teachers draw children's attention to the specific language that indicates likelihood, helping them see the ways writers of science texts choose their language carefully to be accurate about findings or predictions. This feature of the curriculum illustrates how we attend to children's cognitive development and scaffold from everyday understandings to more complex understandings.

One pedagogical tool we introduced for making likelihood a focus of discussion and raising students' awareness about their options for meaning-making in context was a likelihood scale on which students could categorize language they encountered as expressing low, middle, or high degrees of likelihood. ${ }^{1}$ The high end of the likelihood scale uses no modality at all; it is certain. Middle likelihood uses language that indicates less than certainty, and low likelihood introduces language that presents options as only possible. In the context of a brief

\footnotetext{
${ }^{1}$ The reader may be interested to learn that scientists do, in fact, employ a likelihood scale in their writing and have agreed to a quantification of that scale (e.g., Intergovernmental Panel on Climate Change).
} 
(10- to 15-min) mini-lesson, students practiced identifying and using language from the likelihood scale and adding examples to the scale to recognize the range of language resources through which these meanings are made. This feature illustrates how we engage students in the use of metalanguage to both interpret text and compose text.

Then, as they read science texts, children identified the ways likelihood was introduced into the texts and added those language forms to the likelihood scale. This feature illustrates what we mean when we say that our instruction relies upon careful scaffolding. As the texts they were reading were providing them with evidence they would use in writing an argument about the issue they were engaged with, students discussed how sure the author was about the evidence being presented, as indicated in the likelihood language that is used. That kept the focus on meaning in context and supported the children in learning to write arguments with reasoned evidence.

For example, in one fourth-grade classroom, students were reading about the devastating invasion of cane toads in Australia and were introduced to the range of solutions that scientists and officials, eager to control the invasion, have considered. At one point, the text suggested introducing meat ants as a possible solution to the cane toad problem. The teacher asked the students to use the likelihood scale, posted on the wall, to talk about how sure the author was about whether the meat ants might slow the cane toad invasion. The students have read: "The cane toads' toxins are not likely to affect the meat ants." When the teacher asked, "Can we say the toxins from the toad don't affect the meat ants?" a student replied "It's not likely, it doesn't, like they're not definite, they're in the middle."

Through this close analysis of meaning, students engaged in oral rehearsal for writing about the evidence presented in the texts they read, practicing interpreting degrees of likelihood to focus on the ways they could present the likelihood of the evidence they used in their arguments and to adjust the strengths of their own claims. As the children engaged in group work to develop evidence for and against the meat ant solution and added it to a chart at the front of the room, the teacher again focused them on how definite they were in making claims about evidence. As one of the students argued for the meat ant solution, she said, "I think this is a good idea because, uh, it will, uh decrease the population of, uh toads and the ants will help that." The teacher asked the class how sure this is and whether the student needs some likelihood words. Another student responded, "she said the word will and we're not that sure." When asked what they could say instead, a student volunteered, "most likely." In our research, discussions of text are typically followed by asking students to write to a prompt that provides the teacher and researchers evidence of the sense-making 
each student has engaged in during the course of the discussion; the writing also provides an opportunity to determine whether students are taking up the metalanguage to support their own writing efforts.

This example illustrates several of the principles that follow from our theoretical understanding and guide our work:

- The metalanguage supports teachers in engaging ELs in talk about language that helps them understand and write complex texts.

- Interaction about how the language means what it does, both in small group work and in whole-class interaction, provides opportunities for students to use language in ways that support their learning of disciplinary meanings.

- ELs can work with grade-level texts and tasks when they are supported with a focus on meaning in context through interaction with a teacher who is able to use meaningful metalanguage to guide them in developing understanding about language and meaning.

In today's standards-based learning contexts, we need to draw on theories of language, language development, subject-matter learning, and second language learning that provide a coherent basis for supporting children's development of the language resources they need for success at school. We have found the theories discussed here to be valuable resources for guiding our thinking about students, teachers, texts, curriculum, and language development over time in the context of schooling.

\section{ACKNOWLEDGMENTS}

We thank the participants in the Language and Meaning project for their contributions to this work, especially the teachers and children who helped us learn more about how to make talk about language meaningful. The research reported here was supported by the Institute of Education Sciences, U.S. Department of Education, through Grant R305A100482 to the University of Michigan. The opinions expressed are those of the authors and do not represent views of the Institute or the U.S. Department of Education.

\section{THE AUTHORS}

Annemarie Sullivan Palincsar is the Jean and Charles Walgreen Jr. Chair of Reading and Literacy at the University of Michigan. Her research focuses on the design of learning environments that support self-regulation in learning activity, especially for children who experience difficulty learning in school. She has served as a member of the National Academy's Research Council on the Prevention of Reading 
Difficulty in Young Children; the OERI/RAND Reading Study Group, and the National Research Council's Panel on Teacher Preparation.

Mary J. Schleppegrell is a professor of Education and Chair of Educational Studies at the University of Michigan. She has extensive experience introducing teachers to functional linguistics strategies for reading and writing difficult texts. For many years she served as linguistic consultant to the California History Project and has published extensively on the features of academic language and on the language development of English learners.

\section{REFERENCES}

August, D., \& Shanahan, T. (Eds.). (2006). Developing literacy in second-language learners: Report of the National Literacy Panel on Language-Minority Children and Youth. Mahwah, NJ: Lawrence Erlbaum.

Echevarria, J., Short, D., \& Powers, K. (2006). School reform and standards-based education: An instructional model for English language learners. Journal of Educational Research, 99, 195-210. doi:10.3200/JOER.99.4.195-211

Eggins, S. (2004). An introduction to systemic functional linguistics (2nd ed.). London, England: Continuum.

Ellis, N., \& Larsen-Freeman, D. (2006). Language emergence: Implications for applied linguistics-Introduction to the special issue. Applied Linguistics, 27, 558-589. doi:10.1093/applin/aml028

Goldenberg, C. (2008). Teaching English language learners: What the research does and does not say. American Educator (Summer), 8-44.

Halliday, M. A. K. (1978). Language as social semiotic. London, England: Edward Arnold.

Halliday, M. A. K., \& Matthiessen, C. M. I. M. (2004). An introduction to functional grammar (3rd ed.). London, England: Edward Arnold.

Lesaux, N., \& Geva, E. (2006). Synthesis: Development of literacy in second-language learners. In D. L. August \& T. Shanahan (Eds.), Developing literacy in second-language learners: Report of the National Literacy Panel on Language-Minority Children and Youth (pp. 53-74). Mahwah, NJ: Lawrence Erlbaum.

Palincsar, A. S. (1998). Keeping the metaphor of scaffolding fresh. Journal of Learning Disabilities, 31, 370-373. doi:10.1177/002221949803100406

Schleppegrell, M. J. (2013). The role of metalanguage in supporting academic language development. Language Learning, 63(Suppl. 1), 153-170. doi:10.1111/j. 1467-9922.2012.00742.x

Vaughn, S., Martinez, L. R., Linan-Thompson, S., Reutebuch, C. K., Carlson, C. D., \& Francis, D. J. (2009). Enhancing social studies vocabulary and comprehension for seventh-grade English language learners: Findings from two experimental studies. Journal of Research on Educational Effectiveness, 2, 297-324. doi:10. $1080 / 19345740903167018$

Vygotsky, L. (1986). Thought and language. Cambridge, MA: MIT Press.

Wells, G. (1994). The complementary contributions of Halliday and Vygotsky to a "language-based theory of learning." Linguistics and Education, 6(1), 41-90. 